\title{
COMMON-UNITY
}

\section{Rozana Montiel}

Arquitecta, Universidad Iberoamericana, Ciudad de México, México

\author{
Alin Wallach \\ Arquitecta, Universidad Autónoma de México, \\ Ciudad de México, México
}

Azcapotzalco, México,

$2014-2015$

P

A fragmented and semi-abandoned space between residential units is transformed into a common area through this project. The verticality of fences and partitions is replaced by the horizontality of architectural elements able to integrate the community into a common -and also horizontal- process of design, using a strategy that could well be replicated in all those spaces left by the modern utopia and fragmented by the postmodern pragmatism.

KEYWORDS · horizontal, collective, co-ownership, community, participation

Building COMMON-UNITY is a project for rehabilitating the public space in the San Pablo Xalpa housing unit in Azcapotzalco. The unit was divided by walls, fences, and barriers placed by the residents themselves and impeded the use of the available public space. The goal was to transform a partitioned housing complex into a COMMON-UNITY designed by the neighbors and not just for them.

The project strategy was to work with the barriers created by the inhabitants: permeate them, democratize them, and redefine them to generate UNITY within the unit.

Previously, the residents of different sectors implemented temporary coverings in the public area for events and meetings, thus achieving an extension of the private areas. Working with them, we reutilized the idea of covering certain spaces to create recreational and cohabitation spaces. Roofed modules were installed that are more than just a covering, because their facades are equipped for different activities (blackboards, climbing walls, railings, and nets). Also, a multipurpose room was built that the children use as a library.

Thus, the recovered public space became an extension of each apartment. The strategy was effective: the people united to contribute in the redesign of their unit, and such a change was achieved in the perception of the public space that the neighbors themselves requested the removal of the fences. The space spoke for itself, and the inhabitants of the unit made the decision to eliminate the barriers and take advantage of the exterior spaces, filling them with public and common life. ARQ 


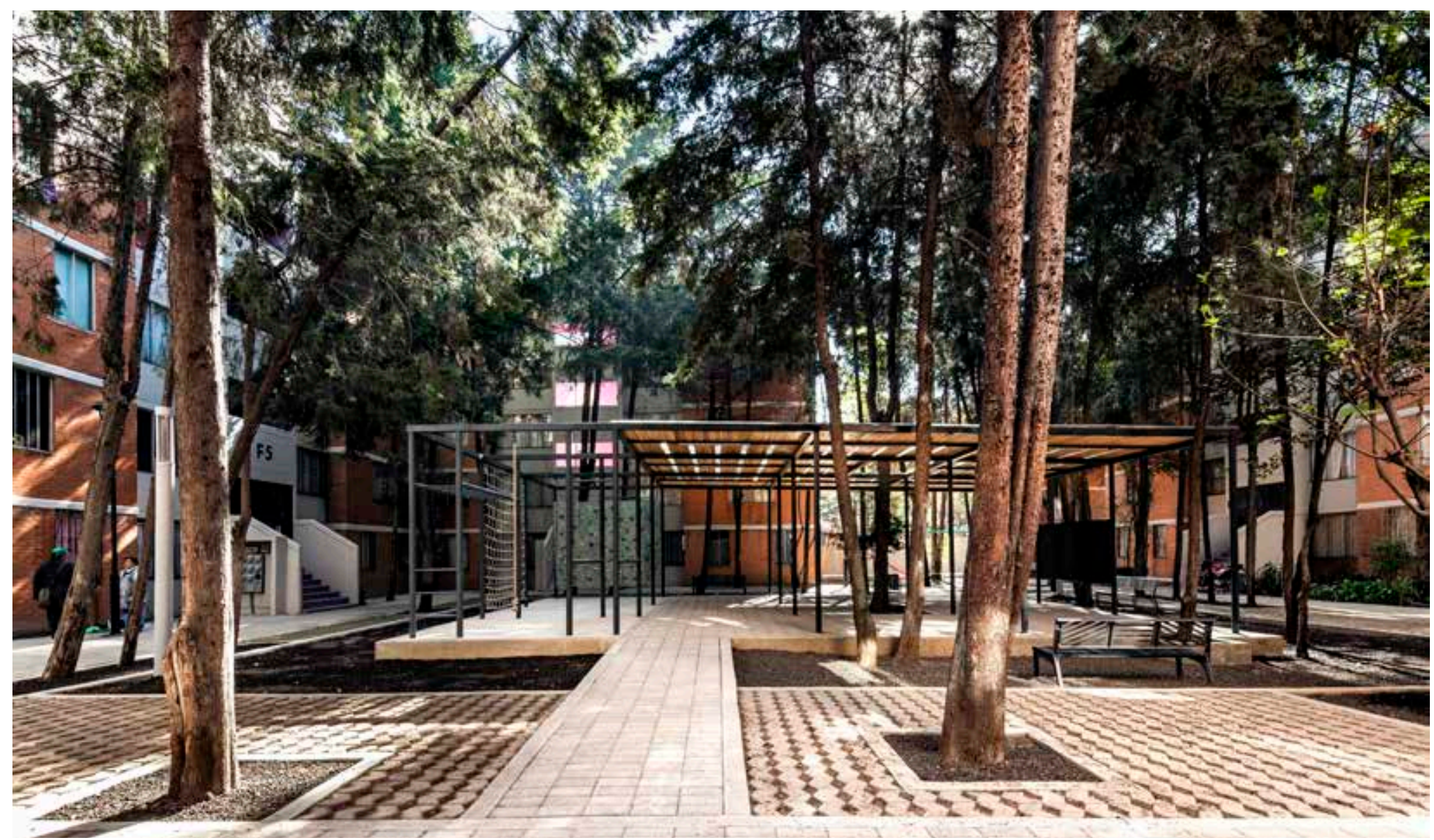

Espacio público rehabilitado / Public space after the intervention

C) Sandra Pereznieto

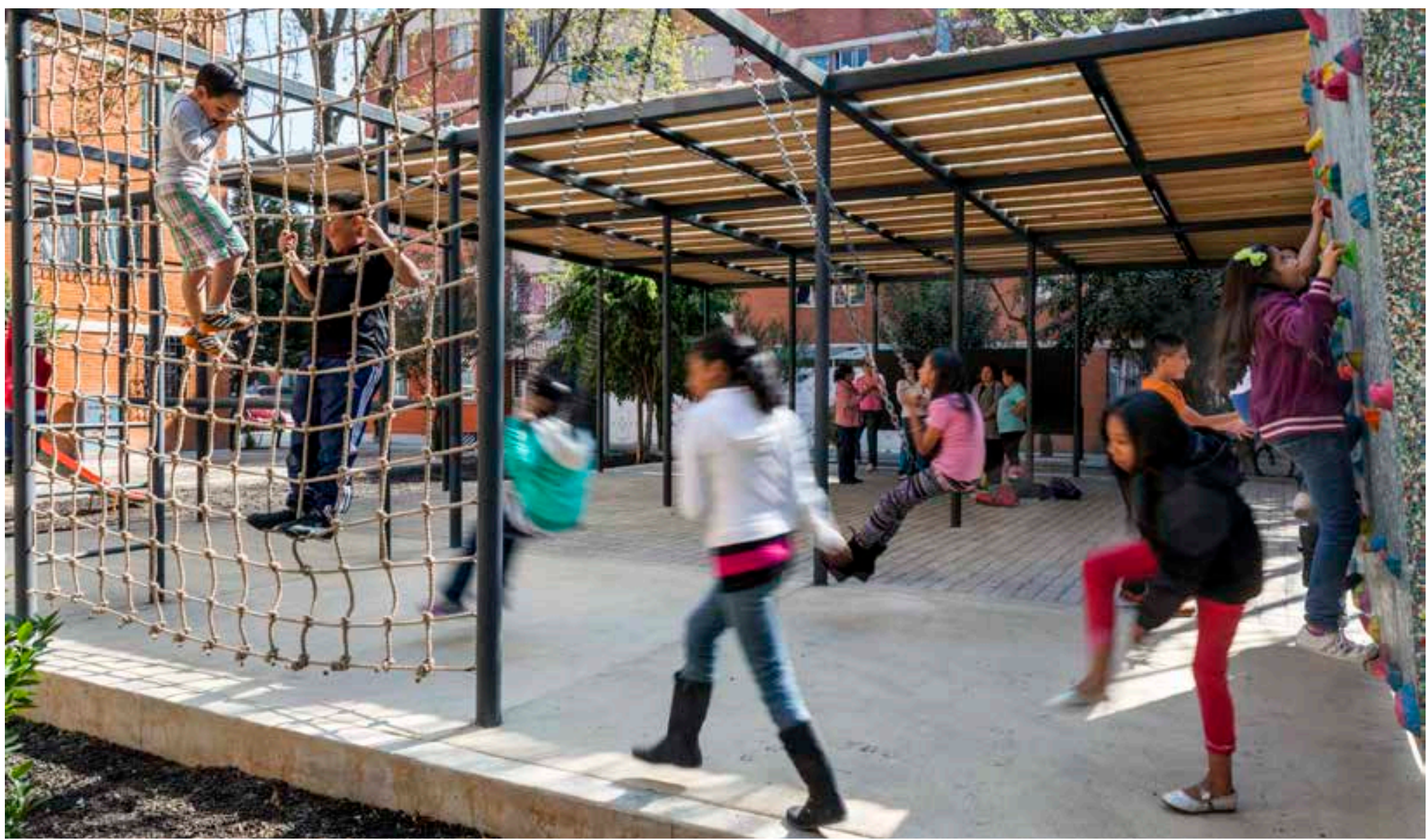


LEYENDA / LEGEND

1. Patio intervenido

Courtyard after the intervention

2. Espacio entre edificios

Space in-between buildings

3. Salón de usos múltiples /

Multipurpose meeting room

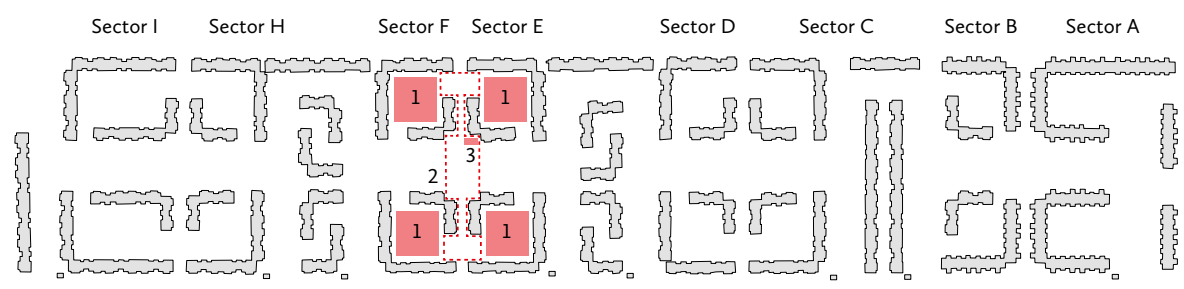
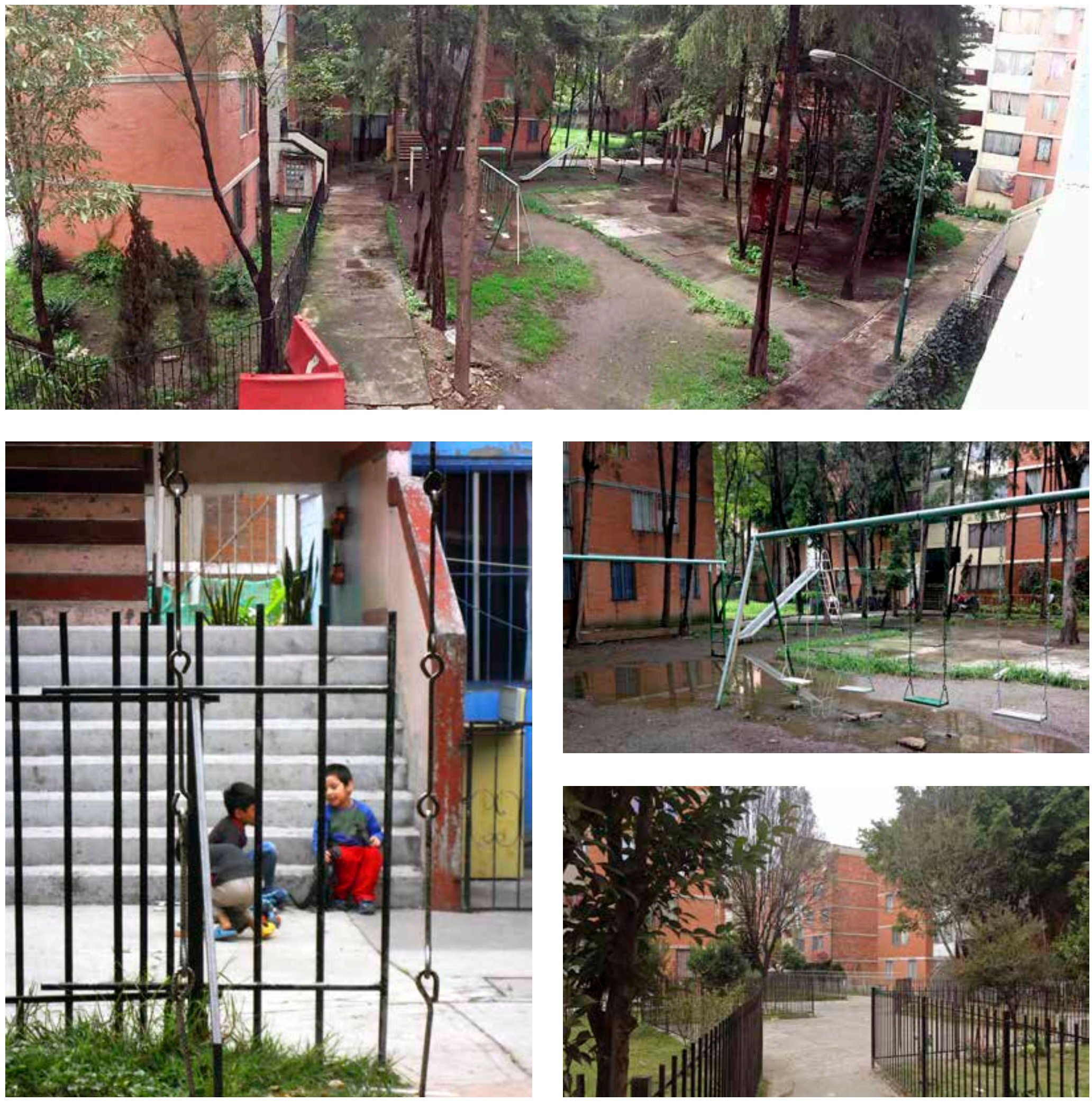

Estado previo del espacio público / Public space before the intervention

(C) Sandra Pereznieto 


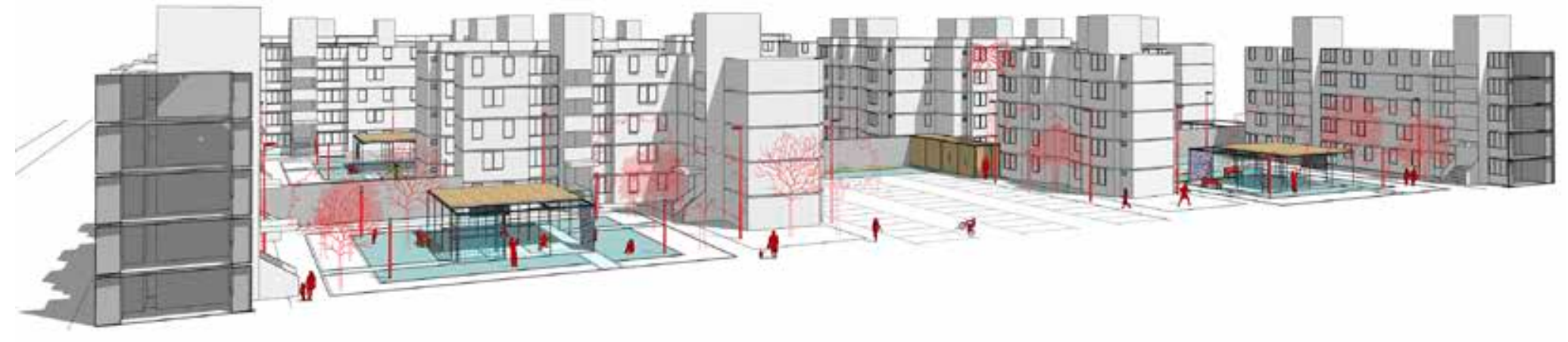

Paneles de fachada / Facade boards S. e. / N. s.
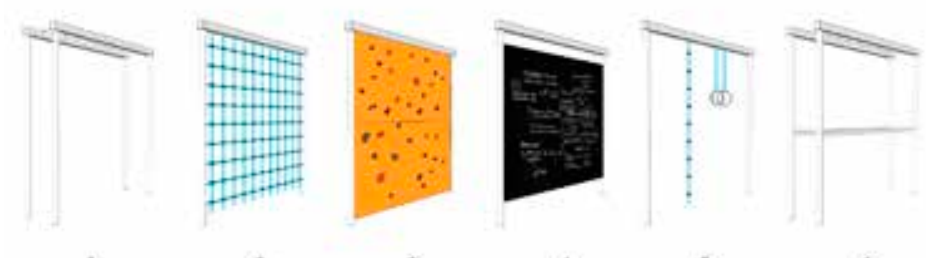

6

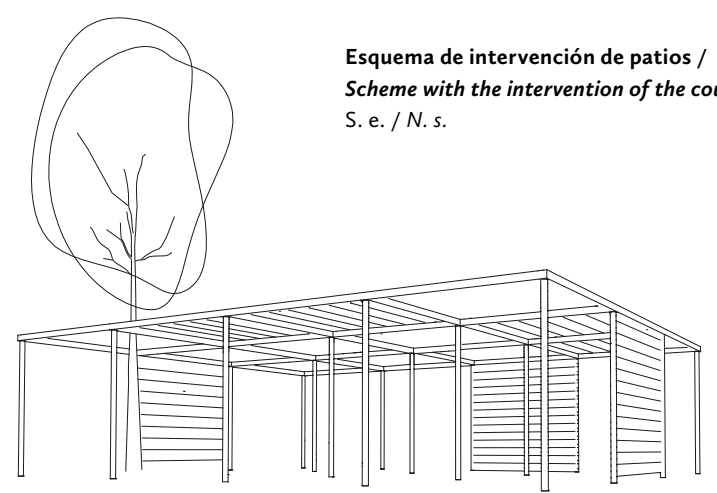

LEYENDA / LEGEND

1. Pasamanos / Handrails

2. Red de escalada /

Climbing net

3. Muro de escalada /

Climbing wall

Planta áreas rehabilitadas / Plan of the intervened areas

E. / S. 1: 1.000
4. Pizarrón / Blackboard

5. Cuerda y aros /

Rope and hoops

6. Barras paralelas /

Parallel bars

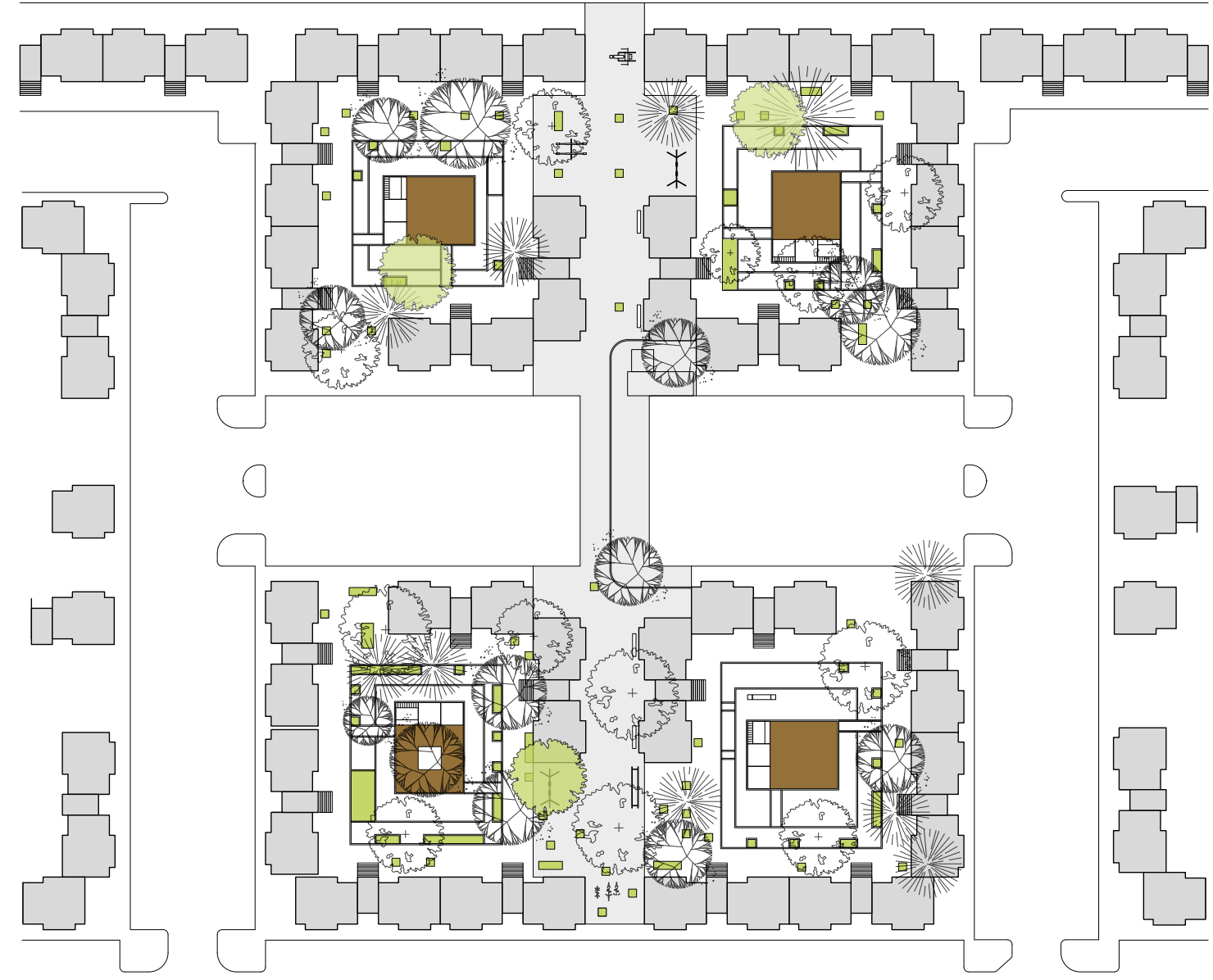

OBRAS Y PROYECTOS $\mathbf{4 7}$ WORKS AND PROJECTS 


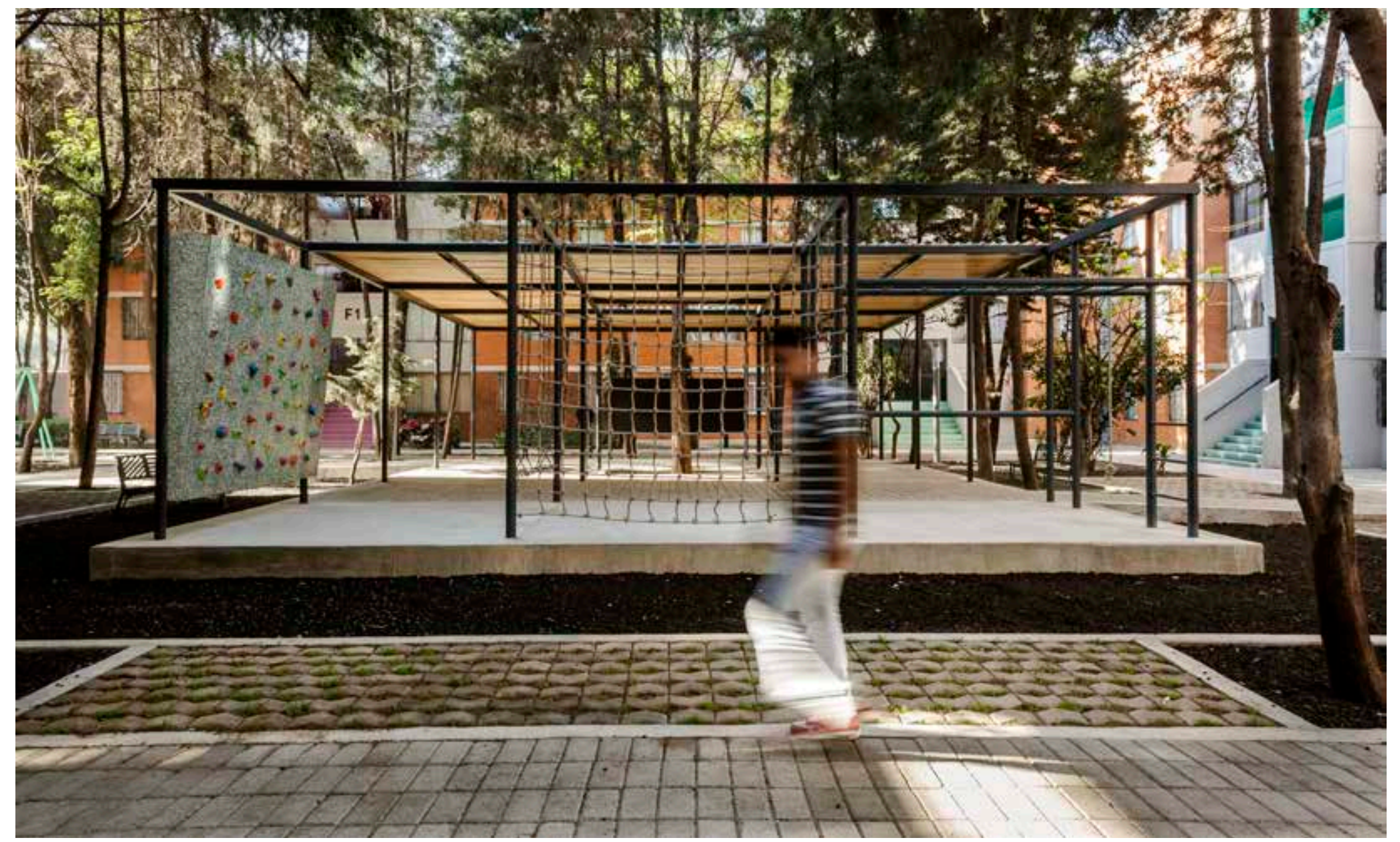

Espacio público rehabilitado / Public space after the intervention

(c) Sandra Pereznieto
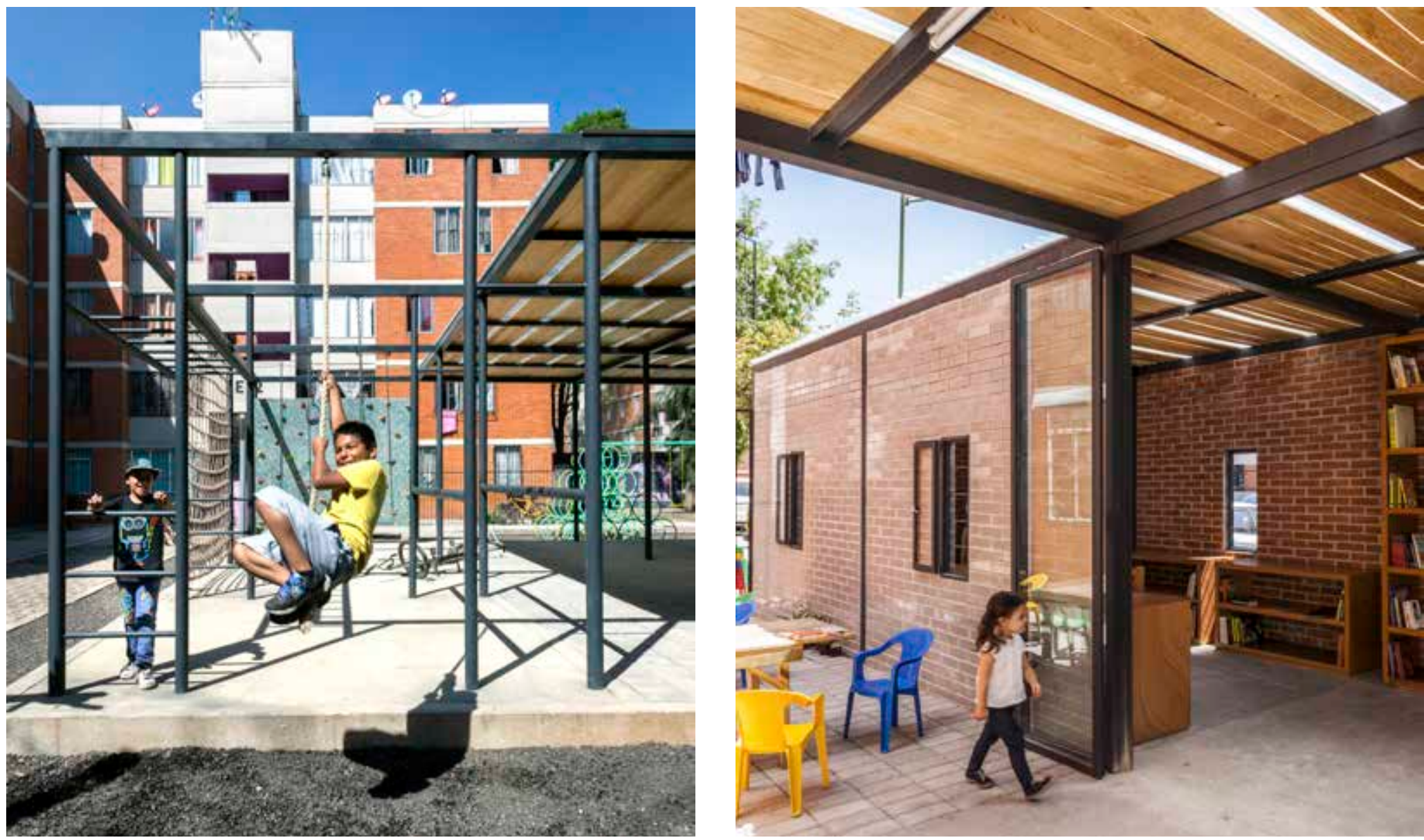

Espacio público rehabilitado / Public space after the intervention 
Arquitectos / Architects

Rozana Montiel, Estudio de Arquitectura Arquitectos asociados / Associated architects Alin V. Wallach

Colaboradores / Collaborators

Cecilia Brañas, Diana León, Valery Michalon, Luis Galán, Alejandro Aparicio Ubicación / Location

Unidad Habitacional San Pablo Xalpa, Sectores E y F. Eje 5 Norte Deportivo Reynosa, Distrito Azcapotzalco, Ciudad de México, México Cliente / Client

INFONAVIT - Instituto del Fondo Nacional de la Vivienda para los Trabajadores

Ingeniería estructural / Structural engineering Sergio López Guevara

Construcción / Building contractor DRAGADOS

Instalación eléctrica / Electrical system Ubaldo Velázquez

Instalación de agua filtrada / Filtered water system ROTOPLAS

Materiales patios / Courtyard materials

Estructura metálica en cubiertas; pavimentos de adoquín de concreto, gravilla negra, pasto, cubierta de lámina translúcida con plafón de madera de pino, muro de escalada con paneles de plástico reciclado multicolor, cuerdas / Metal structure for the roof; pavements made of concrete paver, black gravel, grass, translucent film coverage with pine wood soffit, climbing wall made of multicolored recycled plastic, ropes

Materiales salón multiusos / Multipurpose room materials muros de tabiquería, piso de cemento pulido / Partition walls, floors of polished cement

Presupuesto / Cost

USD $\$ 180 / \mathrm{m}^{2}$

Superficie construda / Built area $5.000 \mathrm{~m}^{2}$

Superficie terreno / Site area

$16.000 \mathrm{~m}^{2}$ (primeras dos etapas / first two stages)

Año de Proyecto / Project year

2014

Año de construcción / Construction year 2014 - 2015

\section{ROZANA MONTIEL}

<rozanamontiel@rozanamontiel.com>

Architect and Urban Planner, Universidad Iberoamericana, Mexico (1998). Master in Theory and Criticism of Architecture, Universidad Politécnica de Cataluña, Barcelona (2000). She is the founder of Rozana Montiel | Architecture Studio, specializing in design, art and urbanism. Thanks to the project COMMON-UNIT she was part of the exhibition "Regional Houses: 32 architectural proposals" at the Museo de la Ciudad de México in 2015.

\section{ALIN V. WALLACH}

<wallach@awarquitectura.com>

Architect, Universidad Nacional Autónoma de México - UNAM(2003). Between 2007 and 2015 she worked at Rozana Montiel Estudio de Arquitectura. Then she founded Aw architecture office and currently collaborates with Dellekamp Arquitectos.

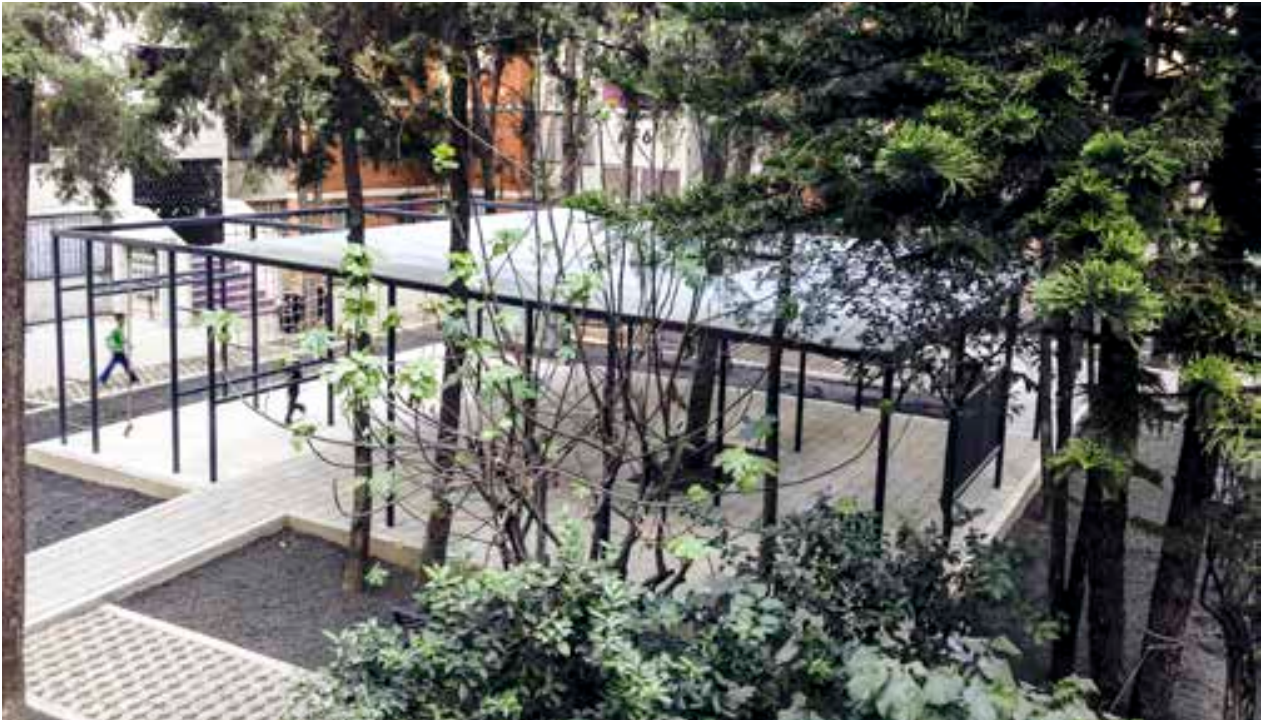

Espacio público rehabilitado / Public space after the intervention (c) Sandra Pereznieto

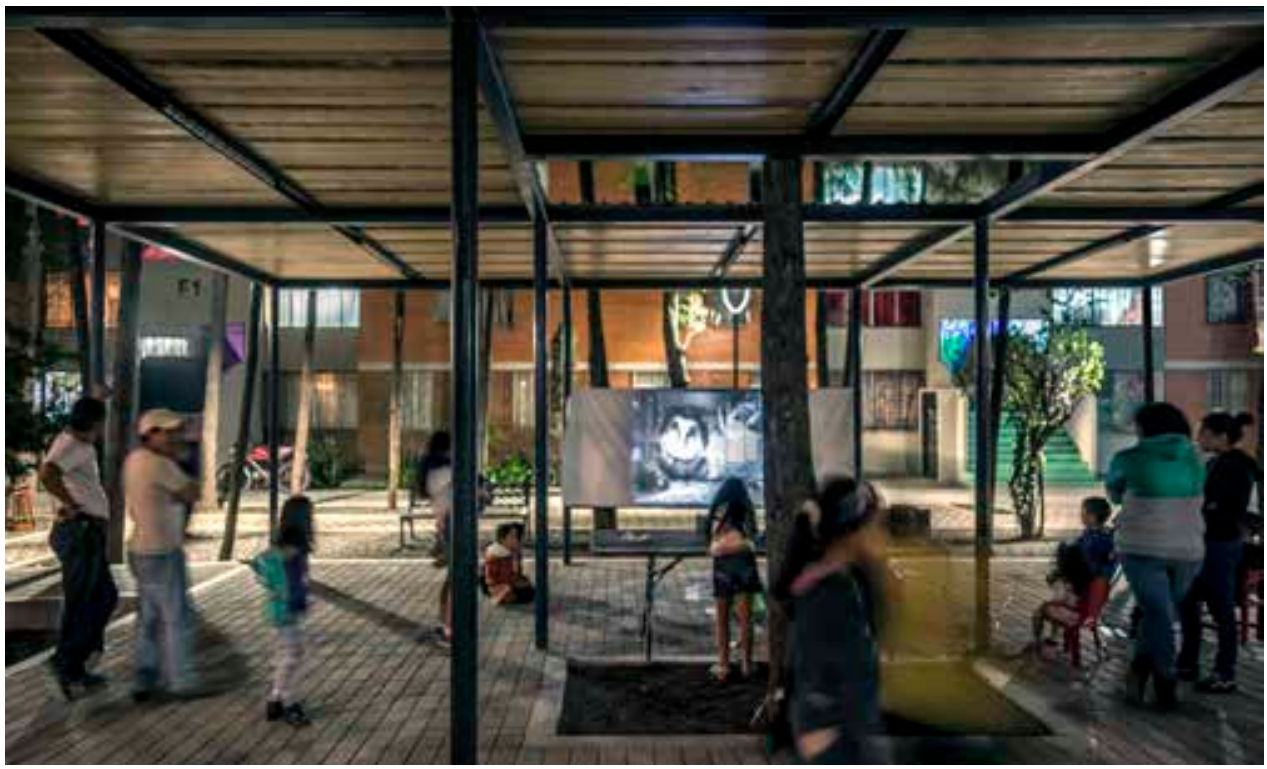

Espacio público rehabilitado / Public space after the intervention

() Sandra Perezniet。

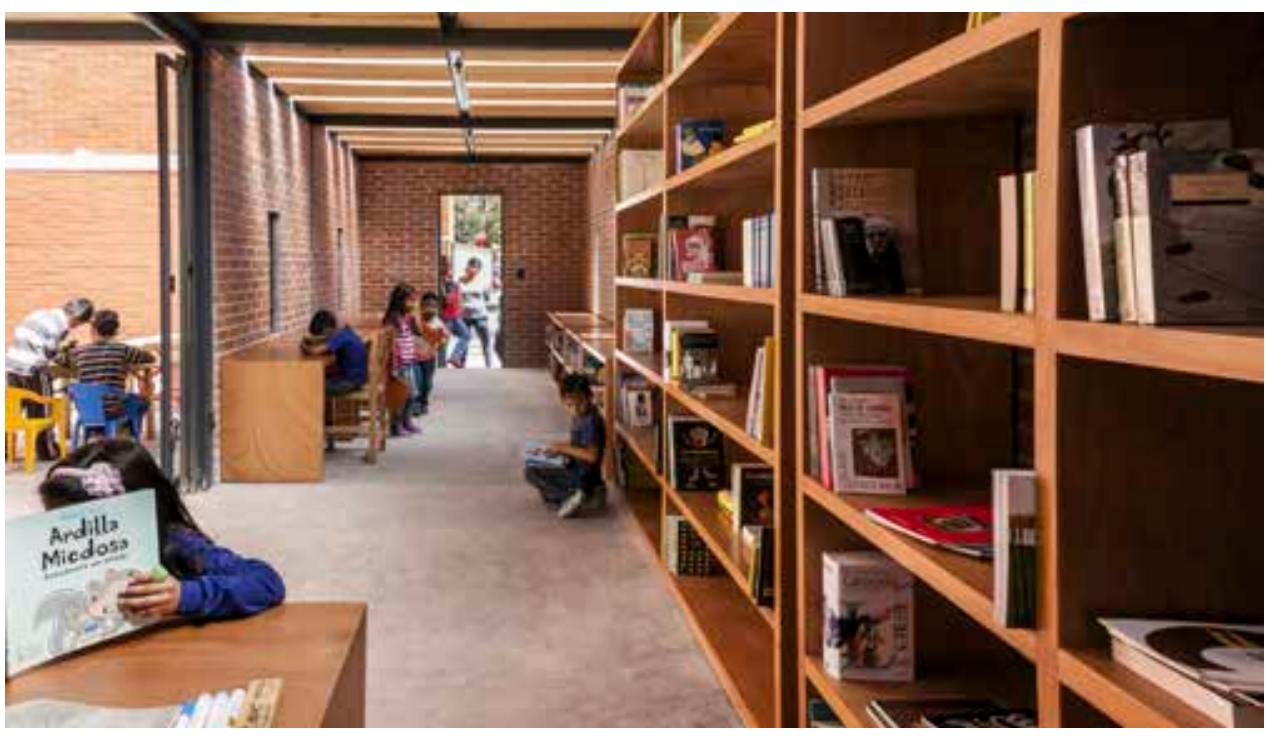

Salón de usos múltiples / Multipurpose meeting room (C) Sandra Pereznieto 